\title{
A Note from the Editor
}

While it is not the practise of the Journal of American Studies to have editorials, this issue marks an exception. We celebrate the 5oth anniversary of the founding of the British Association for American Studies (BAAS), the academic organization which sponsors the Journal, and whose members receive the Journal as one of the benefits of membership. Most practitioners of American studies in the United Kingdom belong to the BAAS, giving it a truly interdisciplinary membership united by interest in the United States as a site of academic study. Members are drawn principally from the ranks of historians, litterateurs, political scientists and analysts of popular culture, along with some geographers, sociologists and economists. Its annual conference draws participants from many nations and at all levels of the academic hierarchy.

The articles included in this special issue testify to the breadth and depth of scholarship associated with the Journal and the British Association for American Studies. Their authors are from England, Scotland, Spain and the United States. Professor Michael Heale, a previous editor of the Journal, and Mick Gidley, an Editorial Board member, consider the origins of American studies in the UK and the work of one of its earliest British proponents. Philip Morgan, the Harry C. Black Professor of History at Johns Hopkins University, gave the Journal of American Studies Lecture at the BAAS conference in 2004. This lecture, sponsored by Cambridge University Press, which publishes the Journal, is one of the highlights of the annual BAAS conference.

We congratulate the British Association for American Studies as it celebrates fifty years of scholarship on American history, culture, politics and society. We wish it many more years as the standard-bearer for academic analysis of the United States in the United Kingdom.

Jay Kleinberg, Editor Susan Castillo, Associate Editor 